\title{
O TEMPO DAS ELEIÇÕES: AS ESPIONAGENS E OS USOS
} DAS LEIS

ELECTIONS PERIOD: SPYING AND THE APPLICATION OF LAWS

\author{
Monique Florencio de Aguiar \\ monique_aguiar@yahoo.com.br \\ Pós-doutoranda pela Unesp, doutora em antropologia pela UFF \\ ORCID: https://orcid.org/0000-0003-3162-5348
}

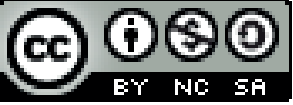

Esta obra está licenciada sob uma licença Creative Commons Attribution-NonCommercial-ShareAlike 4.0 International License.

\section{RESUMO}

Na sociologia, a regulação judicial das disputas políticas foi chamada de judicialização da política e, quando as leis são usadas como arma para prejudicar o adversário, concebe-se que estamos diante de um lawfare. Influenciada por esses temas, neste artigo analiso a mobilização de uma facção política em torno da realização de denúncias à justiça eleitoral, questionando como as leis foram usadas pelos oponentes. Assim, a partir de uma análise reflexiva sobre o trabalho de campo que realizei no contexto eleitoral de um pequeno município do interior do estado do Rio de Janeiro, verifiquei que a espionagem entre os grupos era um elemento central nesta dinâmica de guerra jurídica, pois proporcionava materiais a fim de elaborar denúncias. Sobretudo, evidencio que a guerra jurídica faz parte de um processo histórico no qual o poder judiciário foi fortalecido e que este momento histórico enseja novas questões para a antropologia (da) política.

Palavras-chave: eleições; disputas políticas; guerra jurídica; espionagem.

\section{ABSTRACT}

In the field of Sociology, the judicial regulation of political disputes has been denominated as judicialization of politics. Besides, when laws are used as strategies to disadvantage a political opponent, one can understand that it is characterized as lawfare. Influenced by these themes, in this article the mobilization of one of the political factions regarding the execution of accusations to the electoral justice is analyzed, arguing how the laws were used. Based on a reflexive analysis of the field research performed during the election campaign in a small city located in the state of Rio de Janeiro, the spying perpetrated between groups, a central element in this dynamic of lawfare, was checked; as it enabled the collection of data in order to formulate the accusations. Above all, I show 
that the legal warfare is part of a historical process in which the judiciary was strengthened and that this historical moment raises new questions for the anthropology of politics.

Keywords: elections; political disputes; lawfare; spying.

\section{INTRODUÇÃO}

Neste artigo, proponho analisar a guerra jurídica que se forjou no contexto eleitoral de um pequeno município, no ano de 2008, no Brasil. Portanto, vinte anos depois da promulgação da Constituição de 1988, que proporcionou várias inovações, aplicadas no decorrer do tempo, contribuindo progressivamente para a ampliação do número de acessos à justiça.

Sintetizo a pergunta que me move neste texto: como se deu o uso das leis pelos competidores políticos durante a eleição que será, aqui, analisada? As denúncias à justiça eleitoral revelaram o uso do sistema de justiça com o fim de derrotar os adversários. Contudo, para denunciar algo à justiça e obter sucesso nessas denúncias era preciso obter informações e comprovar o que se dizia. Por isso, existiam vigilâncias mútuas entre os grupos, que consagravam o ato de espionar. A possibilidade de ser alvo de "espiões" tensionava a manutenção de várias relações neste período.

Neste ponto, podemos considerar que passamos da análise da conhecida judicialização da política para a análise do lawfare. O termo lawfare é resultado da junção de "law" e "warfare", significando, em tradução literal, guerra jurídica. Tal guerra se daria quando o sistema jurídico fosse manipulado abusivamente para o alcance de fins políticos.

Apesar de existirem casos icônicos de lawfare no âmbito nacional, escolho analisar como as leis foram usadas por competidores políticos durante uma eleição em um município de doze mil habitantes, no interior do estado do Rio de Janeiro. Assim procedo por acreditar que foi o enraizamento nos locais de uma certa lógica e de uma prática que proporcionou a aceitação, por grande parte da população, do lawfare no contexto nacional. Desse modo, aciono a perspectiva exposta por Foucault (2010, p. 25), de apreender o poder em sua extremidade, onde ele se torna capilar, no plano regional ou local. Em seu campo de aplicação, o poder se materializa em práticas reais e efetivas, circulando e transitando pelos indivíduos (FOUCAULT, 2010, p. 26). A mudança de regime ou de princípios políticos faz parte de um processo histórico pelo qual os instrumentos são construídos coletivamente, ao longo dos anos, e assimilados como válidos por parte da sociedade porque nela já estavam impregnados.

Beneficiando-me de trabalho de campo por mim realizado de fins do mês de maio ao mês de outubro de 2008, pude alcançar naquele terreno 
um modo de agir para lidar com situações de confronto de forças políticas em tempos de eleição. Interagindo com parte dos munícipes, fui elaborando diários de campo. Passei a residir no município pesquisado durante este período e fui construindo uma rede de interlocutores, estabelecendo conversas em comércios, apresentando-me em instituições, solicitando entrevistas e sendo auxiliada por alguns moradores que me indicavam pessoas e fontes de informação. Após o trabalho de campo, analisei o material produzido mediante a minha vivência naquele espaço.

Estruturei este artigo separando-o em cinco subtítulos. No primeiro subtítulo, tratei da noção de guerra jurídica, situando brevemente este fenômeno na história. No segundo subtítulo, apresentei o campo e as posições que se conformavam durante o período eleitoral no local, extraindo da visão dos interlocutores as condições para me verem como "espiã" ou para especularem sobre a minha identidade. No terceiro subtítulo, mostrei as regras da justiça eleitoral como instrumentos utilizados na disputa entre as facções políticas e explicitei exemplos de interpretações sobre essas regras, que conformavam uma gama de intérpretes do direito. No quarto subtítulo, aprofundei a análise sobre a espionagem e sobre as dificuldades que este tipo de estratégia de combate gerou para a obtenção de informações quanto ao planejamento da campanha, redimensionando o conflito e a belicosidade existentes.

\section{O “TEMPO DA POLÍTICA” EM TEMPOS DE GUERRA JURÍDICA}

Ao percebemos uma situação de guerra jurídica, as disputas políticas estão ativas e revelam o faccionalismo existente nos contextos. Oliveira Filho (1977) identificou o surgimento das primeiras referências ao faccionalismo na literatura antropológica nas décadas de 1930 e 1940. Lasswell (1931), Linton (1936) e Murdock (1949) teorizaram sobre o fenômeno, concebendo, em suas abordagens específicas, a facção como um grupo que age de acordo com fins particulares e está vinculado a uma unidade maior. Linton destacou que a facção é constituída pelo líder e seus adeptos e está sempre em oposição a outras. Já para Murdock, a existência de facções caracterizaria uma comunidade como mais pacífica que belicosa, pelo fato da divisão dual permitir a expressão da agressividade de maneira inofensiva. Esta perspectiva está de acordo com a tendência estrutural-funcionalista das décadas de 1930 e 1940, quando uma antropologia política foi delineada por pesquisadores britânicos, que fizeram trabalho de campo na África. O objetivo desses antropólogos era, mediante abordagem sincrônica pela qual se buscavam uniformidades, apreender como as instituições contribuíam para manter o equilíbrio e a coesão do todo social.

No contexto de 1950 e 1960, as sequelas pós Segunda Guerra Mundial eram visíveis e entrou em pauta o fim do colonialismo. Assim, antropólogos britânicos propuseram uma nova abordagem dos fatos políticos dentro do estrutural-funcionalismo. Agora, a ênfase não estava na 
coesão social, na manutenção e na estabilidade dos sistemas políticos, mas na mudança social, nas tensões e nos conflitos. Nesta fase, podemos identificar duas correntes dedicadas à análise de facções: uma que concebe as facções como elementos de organização social e outra que se apoia nas teorias sobre conflitos para examinar as facções (OLIVEIRA FILHO, 1977). Autores como Oscar Lewis, Adrian Mayer, Jeremy Boissevain, Fredrick Bailey, Victor Turner e Fredrik Barth enfatizaram o estudo do comportamento concreto do indivíduo atrelado aos processos históricos e não como algo universal.

Na década de 1970 e início dos anos 1980, o movimento hermenêutico teve seu auge na antropologia. Ele legou um olhar mais compreensivo sobre os fatos políticos, quando se buscou desvendar os significados definidos contextualmente pelos pesquisados por meio de análises densas de microescala. Neste bojo, surgiu uma antropologia da política, com a qual foram exploradas realidades sociais fronteiriças.

No Brasil, ganharam destaque, a partir da década de 1990, as pesquisas sobre política empreendidas por pesquisadores do Núcleo de Antropologia da Política (NuAP), com sede na Universidade Federal do Rio de Janeiro. De acordo com as tendências antropológicas, os pesquisadores do Núcleo escreveram etnografias e buscaram apreender os significados expressos pelos pesquisados em contextos nos quais ações consideradas políticas se faziam presente. O grupo iniciou a sua produção com reflexões sobre a representação política e os processos eleitorais no período de redemocratização do país, redefinindo questões postas pela ciência política e pela sociologia política (ver PALMEIRA, 1992, 1996). Ao pesquisarem em certas "comunidades" rurais situadas no estado de Pernambuco e no estado do Rio Grande do Sul, nos períodos eleitorais dos anos de 1988 e 1990, Palmeira e Heredia destacaram a expressão "tempo da política". O "tempo da política" era o período das campanhas eleitorais, quando os políticos apareciam nas comunidades, rompendo com o ritmo cotidiano das vidas e tornando visíveis os agrupamentos políticos em uma disputa em que o conflito se mostrava aberto (PALMEIRA; HEREDIA, 1993). Em Le temps de la politique, Palmeira e Heredia (1993) escreveram sobre as visitas, as manifestações, os comícios e os desfiles de veículos realizados durante os períodos eleitorais investigados. Esses eventos seriam os componentes do “tempo da política”. É conveniente mencionar que, em Cardoso Moreira, também notei o uso da expressão "tempo da política" pronunciada por moradores.

Para Palmeira (2006, p. 137), no período eleitoral ocorre um realinhamento social das populações existentes nos pequenos municípios, quando as facções são identificadas. Se, de início, o termo facção foi usado para indicar divisões, com o tempo foi atribuída mais autonomia às facções, embora caracterizadas como "grupos não permanentes, não corporados (que só se corporificam na ação)" (PALMEIRA, 2006, p. 18). 
Em Le temps de la politique, chamou minha atenção o fato da menção às acusações desferidas entre os candidatos não ser acompanhada de comentários mais detidos sobre denúncias formais realizadas ao órgão da justiça eleitoral. Cogito, portanto, que as denúncias não eram relevantes quantitativamente e qualitativamente, fazendo com que não ganhassem uma dimensão que as projetassem socialmente. As pesquisas de Palmeira e Heredia (1993) foram realizadas em 1988 e 1990, como mencionei acima, e 1988 foi, justamente, o ano de promulgação da última Constituição brasileira. A partir daí, várias inovações contribuíram para aumentar o número de acessos à justiça.

Atualmente, o poder judiciário tem grande presença nos períodos eleitorais e nas disputas políticas. Para mostrar a intensa regulação judicial sobre as disputas políticas é necessário esclarecer as origens deste fenômeno e suas características. A ascendência do poder judiciário e a importância das Constituições constituem um fenômeno de dimensão mundial.

A implementação do aparelho estatal nas nações sempre foi acompanhada do desenvolvimento de uma cultura jurídica (MIRANDA, 2005, p. 134-135), mas a atuação de agentes do poder judiciário sofreu modificações a partir de reformas estruturais no âmbito do direito, que projetaram o papel do juiz nos assuntos da vida social. Para autores como Vianna, Burgos e Salles (2007, p. 39), essas reformas foram iniciadas logo após a Segunda Guerra Mundial. Com a motivação de prevenir devastações como as realizadas durante a Segunda Guerra, foram incentivadas as elaborações de Constituições que explicitassem valores fundamentais aos quais os soberanos se submetessem (VIANNA et al., 2007, p. 39-40).

Segundo Barboza e Kozicki (2012, p. 59), na Constituição americana de 1787, a ideia da supremacia constitucional já tinha sido adotada e, após a Segunda Guerra, essa ideia foi incentivada internacionalmente. Após longos períodos ditatoriais, países da América Latina, do Leste Europeu e a África do Sul adotaram o constitucionalismo ao implementarem regimes mais democráticos (BARBOZA; KOZICKI, 2012, p. 60). Com a elaboração de Constituições democráticas, Hirschl (apud OLIVEIRA, 2016, p. 106) estimou que três quartos da população do mundo passou por processos de constitucionalização.

Este cenário daria suporte ao processo que Vianna et al. (1999) chamaram de judicialização das relações sociais e da política, pois o poder judiciário surgiu como uma alternativa para a resolução de conflitos coletivos. Com a democratização do acesso à justiça, os autores anunciaram a judicialização das relações sociais. Já com a judicialização da política, os autores evidenciaram uma incorporação indireta do poder judiciário pelos outros poderes, executivo e legislativo.

Contudo, interessa-me pensar na guerra jurídica, ou seja, no momento em que as leis foram mais intensamente acessadas por grupos políticos que se confrontavam. As leis são apresentadas como instru- 
mento em uma guerra que, na verdade, é política. Foucault (2010) associou as análises sobre o poder e a política à forma da guerra. Para ele, se o poder é a manifestação de uma relação de força, deve ser analisado em termos de combate, de enfrentamento ou de guerra (2010, p. 15).

O considerado protagonismo do judiciário, atrelado ao aumento da comunidade de intérpretes do direito, nos conduz ao tema da guerra jurídica. A metáfora da guerra na qual se tem a lei como arma se popularizou a partir de $2001 \mathrm{com}$ um artigo escrito por Charles Dunlap, coronel das Forças Armadas dos Estados Unidos (MATOS, 2019, p. 30). Antes desta popularização, Carlson e Yomans (1975) já tinham empregado o termo lawfare, em 1975, para designar um tipo de duelo realizado com palavras. Na antropologia, a partir da primeira década dos anos 2000, John Comaroff estudou o lawfare remetendo-se ao contexto do colonialismo na África do Sul. Publicações brasileiras também têm sido feitas por juristas a partir do exemplo da Operação Lava-Jato ${ }^{1}$. Cito os trabalhos de Streck (2017), Matos (2019) e Zanin et al. (2019).

Dunlap usou o termo lawfare para se referir a estratégias militares no âmbito das guerras internacionais (MATOS, 2019, p. 228). De início, o autor apontou o lawfare como uma estratégia realizada contra os estadunidenses por atores não estatais (MATOS, 2015, p. 823), que buscariam apoio público, alegando planos ilegais e imorais dos Estados Unidos (MATOS, 2015, p. 830). Em publicação de 2009, afirmou que lawfare era uma estratégia de uso (ou mau uso) da lei em substituição a meios militares tradicionais para alcançar um objetivo operacional (MATOS, 2015, p. 824). Posteriormente, passou a admitir um novo conceito, que não cabia apenas aos contextos de guerra: o uso da lei como meio de realizar o que poderia, de outra forma, requerer a aplicação da força, ou como meio de facilitar o uso da força (DUNLAP, 2015, p. 824). Por fim, Dunlap (2015, p. 838) salientou que os conflitos do século XXI têm o lawfare como característica, inaugurando a "era do lawfare" como método de guerra (DUNLAP, 2015, p. 836).

O conceito de lawfare foi ressignificado a partir de outros contextos pesquisados. Se Comaroff chegou a conceber o lawfare como uma tática que pode ser positiva, a maioria dos autores se remete ao lawfare como o uso predatório ou abusivo do direito (STRECK, 2017; DUNLAP, 2015; MATOS, 2019; ZANIN et al., 2019). A organização Lawfare Project foi criada a fim de trabalhar nos casos de lawfare que envolvem a comunidade judia. Para ela, o lawfare seria o oposto de perseguir a justiça, designando o mau uso de processos legais para intimidar e frustrar oponentes (MATOS, 2017, p. 232; STRECK, 2017, p. 119). Nesse sentido, para Matos (2019, p. 235) "as táticas de lawfare - em seu viés negativo - giram em torno do abuso e/ou manipulação do direito interno ou internacional, com o fim específico de prejuízo a outrem". Em Zanin et al. (2019, p. 21) o lawfare foi definido como "o uso estratégico do direito para fins de deslegitimar, prejudicar ou aniquilar um inimigo". 
Comaroff (2001, p. 305) procurou demonstrar que a lei foi uma ferramenta usada pelos europeus para pacificar e governar povos colonizados. Mas os indígenas, que se viam subordinados, começaram a mobilizar o sistema legal para desafiar hierarquias de poder (COMAROFF, 2001, p. 306). Dessa forma, a lei foi um instrumento de dominação, mas também um instrumento de resistência e luta (COMAROFF, 2001, p. 307). No livro intitulado Law and disorder in the postcolony, os Comaroff (2006, p. 33) escreveram que, algumas vezes, a lei é a arma do fraco ou do marginal na consecução de recursos, reconhecimento, voz, integridade e soberania (COMAROFF; COMAROFF, 2006, p. 31). Entretanto, ultimamente, tem sido a arma dos mais equipados para jogar dentro da dialética da lei e da desordem (COMAROFF; COMAROFF, 2006, p. 31). A lei é o veículo aproveitado pelas oligarquias para seguir com seus interesses econômicos (COMAROFF; COMAROFF, 2006, p. 31).

Em ZANIN et al. (2019), o lawfare ganhou contornos de guerra híbrida movida por impérios estrangeiros em parceria com agentes nacionais e o foco está nas estratégias jurídicas utilizadas por integrantes do próprio sistema de justiça, que deturpam as leis e usam seus cargos e as instituições. A guerra híbrida se caracterizaria pela "conjugação de conhecimentos militares, comunicacionais, jurídicos e psicológicos para substituir os meios tradicionais de batalhas" (ZANIN et al, 2019, p. 33). O lawfare, para ZANIN et al. (2019, p. 15), “ocupa um lugar central na reflexão sobre as combalidas democracias constitucionais contemporâneas".

Assim, o efeito da guerra jurídica na deterioração das democracias é ressaltado ${ }^{2}$. Nesse sentido, lembro um verbete de Tonelli $(2017$, p. 87) sobre a judicialização da política, em que a criminalização da política apareceu como consequência desta judicialização. Para a autora, a soberania popular foi desapossada de seu lugar de protagonista da democracia, já que o poder judiciário não é eleito pelo povo, e alertou: "a democracia é o regime dos direitos, não do Direito” (2017, p. 87). É oportuno lembrar as várias obras que têm surgido ultimamente questionando o vigor democrático, por exemplo, o documentário Democracia em Vertigem (2019), de Petra Costa, e o livro Como as Democracias Morrem, de Levitsky e Ziblatt (2008) ${ }^{3}$.

Os Comaroff argumentaram que, nas últimas décadas, o fetiche da lei aumentou, levando até mesmo à criação de uma fachada de respeitabilidade, em que se pode ter um "governo simulado", em que eleições fictícias são asseguradas (COMAROFF; COMAROFF, 2006, p. 16). Nas eleições argentinas de 2002, os autores constataram que uma inundação de acusações sobre conduta ilegal ou imprópria chegou aos órgãos judiciais (COMAROFF; COMAROFF, 2006, p. 27). Nesse sentido, pretendo abordar as acusações que são levadas à justiça próximo e durante o período eleitoral. 


\section{O CAMPO DE BATALHA: POSIÇÕES EM JOGO E SUSPEITAS}

Para pensar na ocorrência de uma guerra jurídica ou das regras jurídicas como arma numa disputa eleitoral, é necessário antes identificar os atores políticos que estão concorrendo, as condições de observação e a dinâmica da disputa eleitoral.

Cardoso Moreira se tornou município no ano de 1989, mediante um processo de emancipação político-administrativa em relação ao município de Campos dos Goytacazes. No ano de 1992, ocorreu a primeira eleição para os cargos municipais de prefeito e vereador. Renato Jacinto foi o primeiro prefeito eleito, mantendo-se no cargo por quatro anos, durante os quais teve como secretário de obras o tio de sua esposa, Gilson Siqueira. Apoiado por Renato Jacinto, Gilson Siqueira venceu a eleição seguinte. Depois de sua posse no cargo, ocorreu uma cisão no grupo político e parental, que conformou os dois "lados" em disputa: Gilson e seus adeptos versus Renato e seus adeptos. Na sequência, Gilson foi reeleito para mais um mandato à frente da prefeitura. Durante meu trabalho de campo, em 2008, Renato ocupava o cargo de prefeito, o que nos permite dizer que os dois concorrentes haviam ocupado o cargo de prefeito duas vezes e eram candidatos ao mandato que se iniciaria no ano de 2009.

No contexto Cardosense, é possível verificar a assertiva de Oscar Lewis, para quem certas unidades atuariam no sentido de gerar facções (apud OLIVEIRA FILHO, 1977, p. 123). As facções geradas possuíam seus líderes na condição de adversários que mobilizavam competições por recursos, o que para Mayer (2010) e Boissevain (2010) as caracterizam. Ressaltando a dinâmica dos processos e das redes sociais, Boissevain (2010) se posicionou contrário à ideia de grupos permanentes e em equilíbrio, perspectiva que ilumina as mudanças ocorridas no próprio cenário do município aqui em foco.

Almejando obter a confiança dos pesquisados, optei por me envolver apenas com um dos agrupamentos em disputa, o agrupamento dos apoiadores de Gilson Siqueira. A relação de confiança com interlocutores foi sublinhada como algo fundamental para a coleta de informações em pesquisas de campo (por exemplo, em MALINOWSKI, 1976; WACQUANT, 2002; FOOTE-WHYTE, 2005; ZALUAR, 2000). Malinowski (1976, p. 20-21) expôs que, diante das oposições sociais que encontrou nas Ilhas Trobriand, procurou se afastar dos "brancos" para ganhar a confiança dos nativos e se manter em contato, o mais íntimo possível, com eles. Ao contornar este obstáculo inicial, o autor afirmou que a vida na aldeia "assume um caráter natural em plena harmonia com o ambiente que o rodeia” (MALINOWSKI, 1976, p. 21). Diferente da experiência de Malinowski, eu não conseguiria alcançar a harmonia com os pesquisados, pois o conflito social permeava bastante as interações cotidianas. Com isso, os receios quanto à minha presença cederam lugar, por vezes, a intensos bloqueios e animosidades. 
Minha dificuldade em estabelecer relações de confiança com a maioria das pessoas em campo revela as condições de observação com as quais me deparei no local. Como é possível fundamentar a desconfiança de que fui alvo? Passo, então, a cogitar os motivos para tal desconfiança.

Primeiramente, eu nunca havia estado no município antes, sequer conhecia a região na qual ele se situava. Deslocando-me para Cardoso Moreira, fui travando os meus contatos iniciais boca a boca. Neste local, sem contatos familiares e amizades prévias, tão valorizados em um município pequeno como este, tornava-me uma pessoa curiosamente observada por muitos moradores. Em uma cidade onde "todo mundo se conhece" ou "quem não é parente, é amigo", como me disseram, eu só poderia ter minha entrada em campo sob suspeita.

Em segundo lugar, enfatizo a desconfiança com que, geralmente, os moradores recebiam àquelas pessoas concebidas como "de fora" do local. Consideravam que o município não tinha atrativos, como lugares turísticos, infraestrutura, serviços e economia pujantes. Os estranhos àquele local podiam ser possíveis estelionatários almejando aplicar um golpe, podiam ter ido para Cardoso para se esconder por terem praticado alguma irregularidade ou terem mais condições, educacionais e prestígio, para concorrer aos escassos empregos que os munícipes dispunham. Nesse sentido, os "de fora" podiam significar uma ameaça à reprodução social dos moradores, que tentavam preservar o seu espaço social.

Neste ponto, situo um terceiro motivo para as desconfianças em relação a mim: as singularidades das ações no período eleitoral. A desconfiança devida a quem vinha "de fora" foi redobrada ao tentar me aproximar do grupo que participava mais ativamente das campanhas eleitorais. Se a suspeita de estar na disputa com os moradores por algum benefício futuro já me fazia alvo de animosidades, era outra prática singular vigente no tempo das eleições o que mais me tornava um perigo para os membros dos agrupamentos. Esta prática singular era a "espionagem" que acontecia entre os grupos a fim de se obterem informações que seriam usadas para destruir os planos dos adversários, enfraquecendo as forças de seu opositor. Buscar informações sobre o opositor, de forma secreta, a fim de enfraquecê-lo na batalha, não é um fenômeno novo na literatura antropológica sobre os fatos políticos e Boissevain (2010, p. 206) já havia atestado tal empreendimento na década de 1970. No entanto, enfraquecer o opositor, usando de espionagem, para realizar denúncias massivas à justiça, que informassem sobre infrações das regras político-eleitorais, retrata uma nova realidade. Diante desta prática intensiva, facilmente alguns se convenceram de que eu seria mais uma “espiã" em Cardoso Moreira.

O temor quanto à espionagem se agravava em razão da instabilidade de posições políticas ocupadas por moradores entre os períodos eleitorais, instabilidade já indicada em parte da literatura antropológica 
sobre processos eleitorais (PALMEIRA, 1992, 1996, 2006; VILLELA, 2004). As constantes rupturas das relações com os políticos revelavam as, assim chamadas, "mudanças de lado". Essa relativa liberdade para "mudar de lado" aumentava as desconfianças mútuas. A falta de ajudas aos moradores por parte do candidato ou o não cumprimento de suas promessas foram apontados como motivos para a mudança de lado. Essas pessoas ocasionavam incertezas aos candidatos que deviam "separar o joio do trigo", não "dar asas à cobra" ou "ficar com um olho lá e outro cá". Por isso, havia a necessidade constante, por parte dos políticos, de atualizarem os seus vínculos, bem como criarem novos vínculos.

Em quarto lugar, julgo que um dos motivos para eu ser vista com suspeição foi a curta duração do trabalho de campo. Uma relação de confiança requer certo tempo para se estabelecer, sobretudo, em um ambiente conflituoso. Zaluar (2000) realizou sua pesquisa em uma favela do Rio de Janeiro na década de 1980, quando testemunhou um ambiente de dissenso e conflito. Mesmo nesse local, ela conseguiria desenvolver uma relação de amizade, após dificuldades iniciais de inserção. Contudo, devo lembrar que tanto Zaluar quanto Malinowski, que enfrentaram dificuldades no início de suas pesquisas, em suas respectivas épocas e localidades, conseguiram estabelecer relações de amizade no campo por permaneceram nos locais pesquisados por cerca de três anos.

Em quinto lugar, o que contribuía para gerar desconfianças era a incompreensão em torno da tarefa antropológica. Cardoso Moreira tinha baixos índices de escolaridade, o que dificultava o conhecimento sobre uma atividade bastante acadêmica e escassa. A pouca popularidade e praticidade da profissão fizeram com que os organizadores da campanha não soubessem o que esperar de mim, assim, não tinham controle sobre a minha forma de trabalho.

Muito se falou sobre a posição de superioridade do pesquisador em relação aos seus pesquisados como fator de inibição dos interlocutores, dificultando a obtenção de informações norteadas pelas práticas culturais em questão. Mas, como muitas pesquisas demonstraram, inclusive esta demonstrará, há um controle do nativo sobre o conhecimento adquirido pelo pesquisador, que o coloca abaixo do pesquisado na hierarquia situacional. Nesse sentido, Clifford (2011, p. 45-46) destacou a autoridade dos informantes, pois há uma negociação construtiva em andamento durante as pesquisas, que são direcionadas ou circunscritas pelos informantes. Consequentemente, a escrita é também direcionada pelos pesquisados.

As suspeitas em relação a mim eram condicionadas pelas experiências de vida dos meus interlocutores. Essas suspeitas fizeram parte das minhas condições de observação e me levaram a conhecer melhor as questões em jogo no local. A forma que as pessoas me viam resultou no que pude produzir. As dificuldades que tive para pesquisar e me engajar no grupo que planejava a campanha fizeram com que eu percebesse a 
dimensão do conflito existente, quando estava em jogo para muitos, a depender de quem vencesse a eleição, a reprodução das condições de suas vidas ou a sobrevivência social - já que a prefeitura era a maior fonte de renda do município. Acionando a minha capacidade de estranhamento, busquei compreender os poderes e os interesses que se manifestavam e, sobretudo, os instrumentos usados nessa luta.

\section{GUERRA DE INTERPRETAÇÕES JURÍDICAS: AS LEIS COMO INSTRUMENTOS NA DISPUTA}

No âmbito das atividades políticas, a estratégia de acusar e de espalhar rumores é bastante comum (ver PALMEIRA, 1993; ALDRIN, 2005; AGUIAR, 2018). Atualmente, nos períodos eleitorais, existe uma boa probabilidade de algumas acusações resultarem em denúncias formais. Mas a realização de denúncias depende da interpretação das leis e das regras eleitorais, quando os casos concretos são vistos à luz desse arsenal jurídico.

Parte das regras muda de eleição para eleição e, por isso, em ano eleitoral, os ministros do Tribunal Superior Eleitoral (TSE) emitem novas instruções ou resoluções, que não podem contrariar o Código Eleitoral e a Lei das Eleições, bem como outras relativas à matéria. Hierarquicamente, abaixo do Tribunal Superior Eleitoral, temos os Tribunais Regionais Eleitorais (TREs), seus agentes repassam as instruções recebidas, acolhem as denúncias de infração às regras estipuladas e as julgam. Diante disso, os candidatos a prefeito montavam equipes de advogados, especializados na área política e eleitoral, para orientar a campanha e responder aos diários pedidos de esclarecimento realizados por parte do TRE, quando o órgão era acionado por denunciantes e deveria julgar as causas.

O conhecimento sobre as leis e regras alcançou os adeptos mais participativos dos candidatos por meio das coordenações de campanha. Os coordenadores de campanha instruíam os adeptos quanto às regras que deviam ser obedecidas por eles e quanto à forma de realizar as denúncias que, ao prejudicar a campanha do adversário, consequentemente beneficiava o seu candidato a prefeito. Nesse sentido, em uma reunião que antecedeu o movimento de campanha, a coordenadora principal disse aos presentes que o grupo chegou à conclusão de que a campanha ia ser de "porta em porta" porque não era permitido pela justiça a realização de várias coisas, como: veicular músicas de autoria previamente conhecida, realizar versões com as letras das músicas, no comício não se podia veicular músicas que não fossem as do candidato, o volume do carro de som não podia ser alto demais, o carro não podia passar em frente às instituições públicas com o som do alto-falante ligado, não se podia colar adesivos em locais públicos e as placas do candidato deviam ser colocadas do lado de dentro das casas, não evadindo para o espaço público. Diante das restrições, ela solicitou a ajuda das pessoas presentes 
para fiscalizar as ações dos adeptos e as ações de seus opositores. Pediu que se as pessoas vissem adesivos colados, por supostos "infiltrados", em equipamentos públicos, por exemplo, era para retirar. Logo, outra coordenadora falou: "e se ver do outro candidato é para denunciar".

Mas como realizar as denúncias? Um assessor orientou a filmar com o celular ou fotografar se vissem alguma coisa irregular relacionada a um candidato da oposição. A denúncia era presencial, assim, tinham que ir ao TRE, que se situava no município vizinho, e os funcionários do Tribunal é que iriam averiguar. Pelas situações narradas sobre anos anteriores, era claro que essas recomendações partiam de ambos os "lados” em disputa, era uma forma de lutar da qual não se podia, dada a conjuntura, abrir mão.

Portanto, as fiscalizações mútuas eram intensas. Suspeitava-se que, para vigiar as ações do adversário, os partidários instalavam minicâmeras de filmagem em setores estratégicos de certas ruas. Na tentativa de flagrar irregularidades, comentou-se que uma casa foi invadida a fim de se procurar material para "compra de voto", mas nada foi encontrado. Durante as carreatas que circularam, rivais filmavam a passagem dos carros na esperança de registrar alguma irregularidade, como condutores de moto sem capacete ou motoristas sem cinto de segurança, o que forçaria a apreensão dos veículos.

Engajados nas campanhas, os adeptos repercutiam boatos sobre impugnações, multas e processos sofridos por cada candidato. Logo, a quantidade e os conteúdos dos processos eram assuntos das conversas. Panfletos podiam ser colocados debaixo da porta de moradores e a rádio local podia se aliar a algum candidato, bem como o jornal do município e outros da região. Se as impugnações de candidatura sentenciavam o fim das campanhas, as multas podiam impossibilitá-las permanentemente, dependendo do valor a ser pago.

A forma de interpretação das ações dos candidatos gerava confusões e temores. Por exemplo, uma candidata que ensaiava uma quadrilha de festa junina, foi filmada por adversários. Eles poderiam alegar que ela estava promovendo sua imagem fora da época permitida pela justiça. Outro caso foi o de uma adepta que fotografou um carro com adesivos de candidatos de partidos diferentes. Ela alegou ser isto "infidelidade partidária”, contudo, o eleitor pode votar em candidatos de partidos diferentes, não sendo isto uma irregularidade. Com as diversas interpretações em jogo, prestar ajuda a um vizinho foi evitado por um candidato, para não sofrer acusação de comprar votos.

Quase no fim da campanha, eu resolvi fazer uma matéria jornalística para um site da internet sobre o túmulo do Comendador Cardozo Moreira, personagem que deu nome ao município. Um advogado e assessor sentenciou que não se podia noticiar feitos ou expor fotos de Gilson naquele momento. Ele exemplificou que Renato estava quase tendo a sua candidatura cassada por causa de fotos de obras e do próprio can- 
didato que foram veiculadas num telão durante um evento patrocinado pela prefeitura. E se, com a matéria, Renato ficasse mal visto, seria pior, pois estavam sendo acusados de terem "falado mal" dele num site de relacionamento. Segundo o advogado, o momento não era propício e eu deveria aguardar o término da eleição para divulgar a matéria. A lei não dizia, por exemplo, que não se podia veicular obras em telão, mas havia "brecha" para realizar uma acusação a partir disso, portanto era preciso tomar cuidado - declarou-me. Esses códigos tomavam as mentes dos envolvidos na campanha, quando interpretavam e reinterpretavam as regras para tomar as precauções devidas.

Desse modo, as irregularidades podiam ser verificadas, mas também construídas com base em interpretações. Convém demarcar as diferenças entre os sistemas jurídicos da Civil Law e da Common Law a fim de demonstrar um processo pelo qual a interpretação dos juízes foi valorizada. O sistema jurídico concebido como Civil Law teve origem no direito romano-germânico (América Latina e Europa Continental), no qual "o papel atribuído ao Judiciário sempre foi mais restrito" (VERBICARO, 2008, p. 393). Aqui, o juiz era visto como um funcionário ou burocrata, que aplicava, aos casos concretos, normas abstratas, gerais e impessoais (VERBICARO, 2008, p. 393). Já o sistema da Common Law provém da tradição da cultura anglo-saxã e, de acordo com ele, o juiz não é um mero operador da lei e da certeza jurídica, mas possui um papel criativo (VERBICARO, 2008, p. 393). Nas últimas décadas, no Brasil, considera-se que o paradigma da Common Law ganhou espaço, encontrando facilidades para o seu exercício em decorrência da existência de uma Constituição com "textura aberta, normas programáticas e cláusulas indeterminadas" (VERBICARO, 2008, p. 390). Se as normas constitucionais tendem a ser abertas e abstratas, Barboza e Kozicki (2012, p. 63) afirmaram que a norma não existe no texto, apenas existe diante de um caso concreto.

Nesse sentido, o que se via em Cardoso Moreira eram embates com argumentos mobilizados de acordo com interpretações, quando os casos deveriam se adequar ou não às cláusulas judiciais. A interpretação que decidiria o impasse seria a dos juízes, se sobrepondo às interpretações existentes nos processos e elaboradas pelas partes envolvidas.

Ambos os candidatos a prefeito enfrentaram denúncias sobre a distribuição de cestas básicas, mesmo quando as ações eram realizadas por instituições, eram regulares e aconteciam durante anos. A caracterização era a de compra de votos. Havia notícias de que os beneficiários se indignavam com a suspensão dos auxílios por ordem de juízes. Com o tempo, os candidatos foram inocentados. E, um dia antes da eleição, em passeata para apoiar Renato, exibiu-se uma grande faixa com os dizeres: "Confirmado pelo TRE".

As impugnações também ameaçaram ambas as candidaturas. Renato foi acusado de retirar parte do dinheiro correspondente à previdên- 
cia dos funcionários. Este caso foi resolvido por meio do parcelamento da dívida, que foi autorizado pelo Conselho Previdenciário. No caso de Gilson, a denúncia que comprometia sua candidatura era fruto de um fato ocorrido há 11 anos. Ocorreu que, por conta de uma enchente que acometeu Cardoso, ele gastou além do orçamento previsto, mas não além dos recursos da prefeitura. Sobretudo, a Câmara aprovou esse suplemento nos gastos. Ao fim, a candidatura de Gilson foi homologada. O parecer contrário do Tribunal de Contas foi contraposto à aprovação das contas pela Câmara.

As consequências da regulação das campanhas pela justiça eram, de imediato, essas intensas fiscalizações, as inseguranças quanto ao cumprimento das regras e a espionagem, que podia se materializar por meio de filmagens, fotos e gravações divulgadas em horário eleitoral ou levadas à justiça. Os maiores perigos eram as multas e as impugnações. Teoricamente, esperava-se a regulamentação do conflito. Essa abordagem que preza pela regulamentação do conflito nos lembra as teorias dos estrutural-funcionalistas, como Radcliffe-Brown. Contudo, as coisas não funcionam desta maneira, que hoje se tornou simplista, como já foi demonstrado por Boissevain (2010). Contrariando a análise de regulamentação do conflito, Eriksen e Nilsen (2012, p. 112) consideraram que a política é "a arte do possível" e não "a arte do legal", por envolver poder, a política se relaciona com o relaxamento das normas e mesmo com sua quebra. Para os autores, a política não se relaciona com uma lealdade inabalável aos preceitos morais, mesmo porque não são válidos para todos. A política tem uma dimensão manipuladora e é assim que ela frequentemente é realizada (BAILEY, 1971, 2001; BOISSEVAIN, 2010; BARTH, 2000). Por isso, temos que observar para além das regulamentações, pois a prática política se situa, por vezes, na fronteira entre o que é regular e o que é considerado irregular. Apesar disso, é importante lembrar a advertência de Levitsky e Ziblatt (2018, p. 201) a respeito da manutenção de regras informais, como tolerância mútua e reserva institucional, para o funcionamento da democracia: "Quando rivais partidários se tornam inimigos, a competição política se avilta em guerra e nossas instituições se transformam em armas. O resultado é um sistema constantemente à beira da crise".

As práticas denuncistas entre os grupos e, em parte, aqui descritas, se relacionam com qual sentido de justiça? A disputa eleitoral foi vista como um jogo de convencimento e argumentação, em que representações são acionadas e criadas a fim de vencer o adversário. As representações não precisam condizer com a veracidade dos fatos, podem ser blefes, e tudo isso parece fazer parte do jogo estratégico. Nesse sentido, alguns eleitores diziam que os políticos "pregavam mentira". Quem melhor jogasse esse jogo, quem soubesse convencer e angariar adeptos, quem soubesse explorar as fraquezas do adversário, mereceria ganhar a disputa. É oportuno mencionar que os jogos, que se definem pelas 
regras postas, podem se aproximar de um combate em que "o objetivo não é derrotar o adversário no curso de uma luta codificada e esportiva, mas destruir o jogo e inserir um conjunto diferente de regras" (BAILEY, 1971, p. 14). Via-se como justo que os políticos mais habilidosos, que soubessem se defender, vencessem. Existem as regras da justiça e também o que ainda não foi regulado por ela ou é obscuro e constituirá brechas de entendimento para serem exploradas. Este raciocínio leva à acentuação do caráter pragmático da disputa faccional pensado por Bailey (2001), quando as pessoas que lutam em conjunto se mantêm indiferentes à coerência ideológica das causas que sustentam.

\section{A ESPIONAGEM: GUERRA DE INFORMAÇÃO E INFILTRAÇÃO NA FACÇÃO ADVERSÁRIA}

A prática da espionagem foi apontada por Oliveira (2010) e Zenobi (2010) como algo que dificultou suas inserções nos grupos pesquisados e a obtenção de informações durante os seus trabalhos de campo. Por esses contextos, vemos que a acusação de espião é realizada em situações conflituosas, nas quais oposições entre grupos são visíveis. Para Zenobi (2010, p. 471), as causas que levam um antropólogo a ser acusado de espião "devem ser contextualizadas e enquadradas em cada situação particular”. Na direção desta recomendação, sigo relatando as situações que vivenciei e os cuidados que os meus interlocutores tomavam para não serem vítimas de espiões, já que está prática ocasionaria o material para a realização de denúncias judiciais.

De início, o principal local de encontro dos apoiadores de Gilson era a casa do candidato. Na primeira vez em que me dirigi até sua casa, fui recebida por seu filho, que me levou até sua mãe. Pude então me apresentar usando uma declaração da universidade à qual estava vinculada. Naquele momento, conversamos bastante, mas a campanha eleitoral estava prestes a começar oficialmente. Na segunda vez em que me dirigi à casa de Gilson, os preparativos de campanha estavam avançando e a recepção já não foi a mesma.

Em frente à casa, havia uma faixa na qual se encontrava escrito: "Gilson Siqueira convida os filiados do PP-PDT-PV-PT e DEM para a Convenção dia 21/06 às 14 horas”. Por não ser filiada a nenhum desses partidos, eu desejava saber se poderia participar. Ao entrar no quintal da casa, avistei quatro homens atrás de uma mesa. Eu os perguntei sobre Gilson e disseram que ele não estava. Questionaram o que eu desejava e, então, comecei a explicar o meu trabalho, e, após, indaguei se poderia assistir a Convenção. O senhor que estava no centro da mesa se perguntou: "pesquisa sobre Cardoso Moreira..." - em tom de dúvida e desconfiança. Ele indagou a um rapaz mais novo, que era advogado, se o que eu falava era importante. E o rapaz retrucou que era, acrescentando que era para eu entregar por escrito as perguntas, porque deduziram que o que eu queria fazer era uma entrevista. Eu tentei explicar que as minhas 
indagações iriam surgir no acompanhamento das atividades deles em campanha. O senhor, impacientemente, disse para eu ir à Convenção e depois falaria com Gilson. Perguntei por sua esposa, quando tal senhor respondeu que quem decidia o que era importante para passar para eles eram os três em torno da mesa. Eu conclui: "Ah, vocês são os assessores". Não obtive uma boa recepção e o evento me fez pensar que Gilson era inacessível.

Fui à Convenção. No evento, ao conversar com uma coordenadora de campanha, um candidato a vereador a puxou e a levou inesperadamente para outro lugar, sem dar tempo de eu completar o que falávamos. Vim a saber, posteriormente, que o candidato a vereador que a puxou, nos afastando, justificou seu ato dizendo que eu era "espiã de Renato".

Minha identificação como uma espiã era o mais óbvio que podiam pensar, diante das lógicas do momento. Exemplos da importância dessa qualificação abundaram. Certa vez, ao chegar à Câmara de Vereadores, ouvi um deles falando ao telefone. Ele estava se candidatando pelo "lado" de Renato na disputa e dizia, por ocasião de uma reunião na casa de Gilson naquela noite, que iria "botar uma peruca e ir à casa do homem", quer dizer, faria às vezes de espião, escamoteando a sua identidade.

$\mathrm{Na}$ Câmara de Vereadores, em sessão aberta ao público, eu revia fotos em minha câmara digital quando fui chamada para conhecer o presidente. Falei um pouco sobre a minha pesquisa, mas ele não demonstrou muito interesse e nem disposição de ouvir a explicação inteira. Declarou que o tinham dito que eu estava gravando a sessão e se perguntou: "com autorização de quem?". Assim, as barreiras me forneceram a dimensão do conflito e dos sentimentos em jogo.

Para denunciar ao TRE o que supunham ser irregularidades nos atos de seus rivais, os grupos políticos iam em busca de registrar a lesão de uma regra mediante gravações, filmagens e fotografias, pois somente diante de uma prova a justiça eleitoral podia punir os partidos.

Portanto, um espião gravava conversas, fotografava, filmava, enfim, produzia provas secretamente. Isso era algo da mais alta seriedade naquele momento. Dunlap (2015, p. 834) mencionou, em seu texto, gravações ou filmagens feitas por adversários dos Estados Unidos para angariar apoio público, no entanto, essa dinâmica não foi inspecionada pelo autor. Meu gravador, minha câmera fotográfica e mesmo meu caderninho de anotações eram símbolos de gafes durante a pesquisa, que poderiam impossibilitar o meu trabalho. Condicionando-me a este ambiente, minha forma de trabalho se baseou na capacidade de memorizar falas e situações, desenvolvendo uma leitura e um registro mentais de gestos e posições. Evitei sair com bolsa pelas ruas, para que pudessem ver que eu não representava perigo, não usava nenhum instrumento de espionagem. Também iniciava conversas falando de alguém conhecido, para que isso pudesse me inserir em alguma teia de relações. Mas, antes 
de compreender a necessidade de não utilizar os meus instrumentos de trabalho, cometi algumas gafes.

No primeiro evento de campanha, ingenuamente decidi gravar parte da reunião, com gravador de voz de fita K7 em minha bolsa. Logo, alguns homens começaram a me encarar de longe. Um deles perguntou se eu estava gravando, a coordenadora principal de campanha sugeriu que eu desligasse o celular, porque, segundo ela, a bateria gastava muito rapidamente naquela localidade do interior. Alguns dias depois, uma das lideranças perguntou se eu podia dar-lhe aquela fita, pois queriam fazer uma filmagem, mas ninguém se lembrou de filmar, assim ela utilizaria a voz e colocaria outras imagens. Eu disse que podia dar-lhe, sim. Nesse mesmo dia, a coordenadora principal se aproximou de mim, abriu a mão e, em tom rude, disse: "cadê o gravador?" - acrescentando que o queria emprestado, pois precisava de um para tentar gravar um depoimento comprometedor de alguém do "outro lado". Ela acreditava que eu estava gravando as conversas naquele exato momento dentro da casa de Gilson.

Esses episódios evidenciaram uma barreira ao estudo do grupo de campanha. Eu era observada com reservas, minha conduta era indagada e mantinham-me longe dos segredos de campanha. Segundo Miranda (2001, p. 99), "o segredo funciona como elemento diferenciador porque é capaz de criar posições excepcionais", portanto, não compartilhando os segredos, os pesquisados colocavam-me numa posição de subordinação (MIRANDA, 2004, p. 140).

Os senhores que me receberam na segunda vez em que fui à casa de Gilson, não ficariam sempre sob a casa. O rapaz mais novo, advogado, viria a me tratar sempre bem, a não ser na época mais acirrada da campanha, quando notavelmente todos estavam estressados e saturados. Nesse momento, minha tarefa se reduzia a não atrapalhar e conversar com os menos engajados. O senhor que falou comigo de maneira defensiva, em minha segunda visita à casa de Gilson, não me dirigiria uma palavra sequer no decorrer da pesquisa, a não ser certa vez, quando a esposa de Gilson me chamou para subir no palanque e ele se pôs na frente, me dizendo um sonoro "não". Ele sempre me olharia ameaçadoramente sem dizer nada e não responderia aos meus cumprimentos. Desvendei, ao conversar com alguns, que ele era extremamente "fiel" ao candidato, que não teria "defeitos", a seu ver.

Lembro-me das pesquisas sobre o exército realizadas por Piero Leirner (CASTRO; LEIRNER, 2009), nas quais a dificuldade de penetração no campo parecia por vezes intransponível. Um trecho da obra de Leirner se coaduna com minha situação àquela época: 'eu ia comendo pelas beiradas'.

Como explicitei em outro texto, um recado foi muito claro em outra ocasião: "Piero, sopa quente se toma pela borda". É preciso sempre estar atento ao lugar que se ocupa nessa cadeia e, a partir daí, saber as trocas que são possíveis e as que não são (LEIRNER, 2009, p. 43). 
Diferente, no entanto, do estudo de Leirner, eu estudava relações espraiadas numa cidade e não em uma instituição específica. Assim, driblei as barreiras, permanecendo nas "bordas", tendo acesso a comentários simples, mas que sinalizavam a percepção da população sobre a política. Por isso, não me mantive na dependência de ser aceita no grupo de campanha. O lugar que eu ocupei naquela teia de relações, sempre questionado e cercado por dúvidas, foi, no mínimo, o de uma pessoa "de fora" do local, com a qual deveriam ter sempre cuidado. Quem é "de fora" se situa em posição exterior ao controle social local, gerado através de compromissos morais, e termina por estabelecer uma existência fugidia, ideal para os fins de um espião.

As precauções quanto à minha presença, mais ao fim da campanha, foram explicadas pela coordenadora geral: "eles fazem isso, chamam gente de fora [para espionar]”. Tomar cuidado com exógenos ao seu universo era uma recomendação diante de um momento tão polarizado como uma campanha eleitoral em um pequeno município do interior. No plano internacional, isso encontra eco nos alertas feitos pelo Papa Francisco, em junho de 2019, sobre o lawfare:

[...] manifestar a minha preocupação relativamente a uma nova forma de intervenção exógena nas arenas políticas dos países através da utilização abusiva de procedimentos legais e tipificações judiciais. O lawfare, além de colocar em sério risco a democracia dos países, é geralmente usado para minar processos políticos emergentes e tende a violar sistematicamente os direitos sociais. [...] é essencial detectar e neutralizar esse tipo de práticas que resultam de uma atividade judicial imprópria combinada com operações multimidiáticas paralelas (Discurso na Cúpula Pan-americana de Juízes sobre Direitos Sociais e Doutrina Franciscana apud ZANIN et al., 2019, p. 21-22).

Zanin et al. (2019) reservaram algum espaço em sua obra para narrar práticas de espionagem. Primeiro, mencionaram a publicização, em 2013, de um documento da Agência Nacional de Segurança dos Estados Unidos (NSA), que indicava a espionagem realizada pelos norte-americanos na empresa estatal de petróleo e gás brasileira (Petrobras) e contra dezenas de autoridades do primeiro escalão da República (ZANIN et al., 2019, p. 117). Em segundo lugar, os autores relataram espionagens, como escuta telefônica, ao escritório de advocacia que defendia o ex-presidente do Brasil, Lula da Silva, pelo Juízo da Operação Lava-Jato a fim de se antecipar contra as estratégias da defesa (ZANIN et al., 2019, p. 97).

As interferências exógenas podiam representar um perigo de espionagem, mas é importante salientar que a demarcação dos limites dos agrupamentos, com as constantes "mudanças de lado", era uma tarefa problemática para os candidatos e seus adeptos. Essa dificuldade de traçar a fronteira do grupo é acrescentada à necessidade de conquistar votos dos moradores que precisam ser convencidos, principalmente os que, em períodos anteriores, não foram eleitores do candidato. Os can- 
didatos se movem entre os agrupamentos, eles sentem a necessidade até mesmo de se infiltrar nos agrupamentos dos adversários, seja de forma explícita ou de forma indireta e enganosa, na condição de espião.

Nos últimos dias que antecederam a eleição apreciada, a vigília ao grupo adversário foi realizada também durante a madrugada, quando os mais engajados na campanha se revezaram. A intenção era flagrar algo comprometedor, como atos de compra de votos que pudessem ser denunciados, e inibir tais práticas, pois elas podiam resultar em menos votos para o seu candidato.

\section{CONCLUSÃO}

A regulação judicial das disputas políticas durante as eleições não obteve muitas análises na antropologia da política. $\mathrm{O}$ recurso à justiça eleitoral foi se intensificando após a promulgação da Constituição de 1988. Por isso, propus analisar a mobilização das facções políticas em torno da realização de denúncias à justiça eleitoral.

Elegendo a guerra jurídica em períodos eleitorais como tema central, debrucei-me sobre uma campanha específica ocorrida em 2008, no município de Cardoso Moreira. Minha "observação participante" só pôde ser realizada pelas "beiradas" de um núcleo duro que comandava a campanha do candidato de um dos lados em disputa. É justamente perscrutando o infinitesimal que acredito poder contribuir para a análise do tema, já que a literatura privilegiou a guerra jurídica no âmbito internacional e, posteriormente, nacional.

A realização de denúncias à justiça eleitoral, comprometendo o rival, era uma forma de minar candidaturas, buscando e criando falhas para explorá-las judicialmente. Assim, as denúncias judiciais constituíam armas, entre outras, mobilizadas pela força manipuladora dos que fazem política. Concebidas como armas, num jogo estratégico, as denúncias podiam conformar verdadeiras guerras jurídicas. As interpretações sobre as leis constituíam os golpes no adversário. Os confrontos, portanto, também se davam paralelamente aos eventos de campanha, entre as interpretações dos advogados dos grupos oponentes.

Os adeptos exploravam as brechas das leis e buscavam por outros sentidos que poderiam se relacionar com alguma cláusula mais genéri$\mathrm{ca}$, tanto para se protegerem quanto para denunciarem seus opositores. O blefe, usado para convencer o eleitorado e até a justiça, fazia parte do jogo eleitoral, em que versões ou interpretações sobre os fatos estão em disputa. Dessa forma, os líderes e seus adeptos iam usando as leis com o propósito de vencer a eleição. Para isso era preciso minar as forças dos rivais, com multas, impugnações e fazendo recair sobre eles o desprestígio. Parecia aos adeptos ser justo que os mais habilidosos na arte do convencimento vencessem. No uso distorcido das leis ou na manipulação da justiça, primeiro se escolhe o inimigo, a pessoa a ser denunciada, e só depois são procuradas as infrações que lhe vão imputar. 
Gostaria de enfatizar três pontos para finalizar este texto. São contribuições para refletir sobre: (1) a literatura focada na guerra jurídica, (2) o processo histórico que culminou em guerras jurídicas e (3) a própria antropologia dedicada aos fatos políticos.

Primeiramente, na literatura sobre lawfare (como o fenômeno foi mais recorrentemente denominado), os pesquisadores dedicaram pouco espaço às reflexões sobre a espionagem. Sabemos das clássicas espionagens realizadas durante as guerras tradicionais e tal prática merece um maior aprofundamento analítico ao considerarmos o lawfare. A espionagem, que os políticos e seus adeptos tanto tentavam evitar, faz parte dos contextos em que as leis são usadas como arma numa disputa por poder. Por isso, os oponentes buscam por aliados, internos ou externos ("de fora" do circuito em questão ou "de fora" do âmbito restritivamente político), com os quais os seus interesses convirjam. Isso se revelou para mim pela própria forma como fui tratada por parte dos moradores no período eleitoral, que se punham a construir interpretações sobre mim e minha função, por vezes, identificando-me como "espiã" em benefício do grupo rival. O recrutamento de espiões, usados como elementos exógenos àquele universo ao qual se infiltram, é uma tática na guerra jurídica. Caberia ao grupo atacado identificar os espiões em seu meio e identificar quem ou que grupo eles representam.

Em segundo lugar, alguns autores, como Matos (2019, p. 240-241), apontaram que o lawfare remonta à própria existência do Brasil, pelo constante mau uso do direito para finalidades políticas. O lawfare seria, então, uma nova denominação de um fenômeno antigo (MATOS, 2019, p. 244). Contudo, tentei demarcar que o uso do direito como arma se intensificou nas lutas entre lados políticos a partir de uma espécie de globalização das leis com o fortalecimento de processos constitucionais e democráticos em massa nos países do globo. Com os desastres humanos ocorridos na Segunda Guerra Mundial, acreditou-se que as leis deveriam ser fortalecidas a fim de frear tiranos que, porventura, assumissem o poder executivo. O poder judiciário foi ganhando ascendência progressivamente, chegando a ser um ator político que pode manobrar interpretações legais - como nos mostrou a literatura sobre a judicialização da política e o lawfare no judiciário. Tornar o poder judiciário mais acessível, com as inovações da Constituição brasileira de 1988, contribuiu para um efeito colateral inesperado: a batalha mediante recurso massivo aos tribunais. Portanto, há um processo histórico que levou à intensificação da atuação ou da mediação da justiça nos conflitos políticos, em que o direito pode ser acionado estrategicamente e até de forma abusiva.

Em terceiro lugar, gostaria de demarcar os dilemas pelos quais passa a antropologia da política, que representara avanços teórico-metodológicos em relação à antropologia política. Para aumentar a compreensão dos fatos políticos, perante um mundo cada vez mais interconectado, 
não é suficiente manter-se no nível das microanálises, mas convém uni-las às análises de macroescala. Com isso, metodologias de pesquisa estão sendo reinventadas. Por outro lado, podemos apontar as perguntas pertinentes a cada fase da antropologia. Para os antropólogos políticos das décadas de 1930 e 1940, a pergunta central era como os sistemas sociais se mantinham em equilíbrio e harmonia. Para os antropólogos políticos da década de 1950 e 1960 a pergunta principal era como os sistemas políticos mudam e como os indivíduos canalizam seus conflitos sociais. Para os antropólogos da política a pergunta poderia ser como nativos refletem e interpretam a sua realidade, dando a ela significado mediante o uso de símbolos. Atualmente, especulo que a pergunta central que tem se delineado é como regimes e instituições (em maior medida vistos como democráticos) se deterioram, se desorganizam, se desfazem e entram em colapso. O mesmo pode ser colocado para os indivíduos.

\section{NOTAS}

1. A Operação Lava-Jato é uma investigação conduzida pelo Ministério Público brasileiro, iniciada em março de 2014, com o fim de apurar esquemas de lavagem de dinheiro e demais ações enquadradas como corrupção. A Operação possui vários desdobramentos, com prisões e delações premiadas, e atingiu diversos políticos e funcionários de alto escalão.

2. Como a democracia não é o foco de análise deste trabalho, limito-me a esclarecer que tenho em mente, ao falar em democracia, um sistema de governo em que os representantes são eleitos pelos cidadãos, que gozam de direitos civis, políticos e sociais, sendo iguais perante a lei e podendo participar de decisões políticas e cobrar seus líderes.

3. Em Democracia em Vertigem a autora narra o processo político brasileiro, centrando-se no ambiente polarizado que resultou no golpe de Estado jurídico-político contra a ex-presidente Dilma Rousseff em 2016. No livro Como as Democracias Morrem, os autores examinam o processo recente de colapso de democracias, que são enfraquecidas de modo legal, pela erosão das instituições desde o seu interior. Dificilmente ocorreriam tomadas violentas de poder típicas dos regimes militares das décadas de 1960 e 1970 na América Latina.

\section{REFERÊNCIAS}

AGUIAR, Monique Florencio de. "Questão política”: programas públicos e acusações entre mediadores. Revista de Antropologia, v. 61, p. 124-155, 2018.

ALDRIN, Philippe. Rumeurs: il n'y a pas que la vérité qui compte. Comprendre Les Rumeurs, n. 164, 2005.

BAILEY, Fredrick. Un système politique; leaders et équipes. In: BAILEY, Fredrick. Les Règles du Jeu Politique. Paris: Presses Universitaires de France, 1971. 
BAILEY, Fredrick. Factions. In: BAILEY, Fredrick. Treasons, stratagems and spoils: how leaders make practical use of beliefs and values. Colorado: Westview Press, 2001.

BARBOZA, Estefânia Maria de Queiroz; KOZICKI, Katya. judicialização da política e controle judicial de políticas públicas. Revista Direito $G V$, v. 8, n. 1, p. 59-86, 2012.

BARTH, Fredrik. O Guru, o iniciador e outras variações antropológicas. Rio de Janeiro: Contra Capa, 2000.

BOISSEVAIN, Jeremy. Apresentando "amigos de amigos: redes sociais, manipuladores e coalizões”. In: FELDMAN-BIANCO, Bela (org.). Antropologia das sociedades contemporâneas: métodos. São Paulo: Editora UNESP, 2010.

CARLSON, John; YOMANS, Neville. Whither Goeth the Law: humanity or barbarity. In: SMITH, Margareth; CROSSLEY, David. The Way Out: radical alternatives in Australia. Melbourne: Lansdowne Press, 1975. Disponível em: <www.laceweb.org.au/whi.htm>. Acesso em: 30 mar. 2020.

CASTRO, Celso; LEIRNER, Piero. Antropologia dos militares: reflexões sobre pesquisas de campo. Rio de Janeiro: FGV, 2009.

CLIFFORD, James. Sobre a autoridade etnográfica. In: CLIFFORD, James. A experiência etnográfica: Antropologia e literatura no século XX. Rio de Janeiro: Editora UFRJ, 2011.

COMAROFF, Jean; COMAROFF, John L. Law and Disorder in the Postcolony: an introduction. In: COMAROFF, Jean; COMAROFF, John L. (ed.). Law and disorder in the postcolony. Chicago: University of Chicago Press, 2006.

COMAROFF, John L. Colonialism, culture, and the Law: a foreword. Law \& Social Inquiry, v. 26, n. 2, p. 305-314, april 2001.

DUNLAP Jr., Charles J. Lawfare. In: MOORE, John Norton; ROBERTS, Guy B.; TURNER, Robert F. National Security: Law \& Policy. Durhan: Carolina Academic Press, 2015.

DUNLAP, Charles. A Guerra Jurídica: uma introdução. Military Review, p. 47-57, out./dez. 2017.

ERIKSEN, Thomas Hylland; NIELSEN, Finn Sivert. História da Antropologia. Petrópolis: Vozes, 2012.

FOOTE-WHYTE, William. Sociedade de Esquina. Rio de Janeiro: Jorge Zahar Ed., 2005.

FOUCAULT, Michel. Em defesa da sociedade: curso no Collège de France (1975-1976). São Paulo: Editora WMF Martins Fontes, 2010.

LASSWELL, H. The Measurement of Public Opinion. The American Political Science Review, v. 25, n. 2, p. 311-326, 1931.

LEVITSKY, S.; ZIBLATT, D. Como as democracias morrem. Rio de Janeiro: Zahar, 2008.

LINTON, R. The study of man: an introduction. New York; London: D. Appleton-Century Company, 1936. 
MALINOWSKI, Bronislaw. Argonautas do Pacífico Ocidental. São Paulo: Abril Cultural, 1976.

MARCUS, George E. Ethnography in/of the world system: the emergence of multi-sited ethnography. Annual Review of Anthropology, v. 24, p. 95-117, 1995.

MATOS, Erica do Amaral. Lawfare: uma introdução ao tema e uma aproximação à realidade brasileira. Revista Brasileira de Ciências Criminais, v. 27, n. 161, p. 227-248, novembro 2019.

MAYER, Adrian. A importância dos quase grupos no estudo das sociedades complexas. In: FELDMAN-BIANCO, Bela (org.). Antropologia das sociedades contemporâneas: métodos. São Paulo: Editora UNESP, 2010.

MIRANDA, Ana Paula Mendes de. Segredos e mentiras, confidências e confissões: reflexões sobre a representação do antropólogo como inquisidor. Comum, Rio de Janeiro, v. 6, p. 91-110, 2001.

MIRANDA, Ana Paula Mendes de. Arquivo Público: um segredo bem guardado?. Antropolítica, n. 17, p. 123-149, $2^{\circ}$ sem. 2004.

MIRANDA, Ana Paula Mendes de. Antropologia, estado moderno e poder: perspectivas e desafios de um campo em construção. Revista Ava, n. 7, 2005.

MURDOCK, G.P. Social Structure. New York: The MacMillan Company, 1949.

OLIVEIRA, Fabiana Luci. Agenda suprema: interesses em disputa no controle de constitucionalidade das leis no Brasil. Tempo Social - Revista de Sociologia da USP, v. 28, n. 1, p. 105-133, 2016.

OLIVEIRA, Wilson José Ferreira de. O Antropólogo como um "Espião": quando a observação participante põe em "risco" as fronteiras dos grupos estudados. Revista Pós Ciências Sociais, v. 7, n. 14, p. 123 142, 2010.

OLIVEIRA FILHO, João Pacheco de. Capítulo teórico sobre faccionalismo. As facções e a ordem política em uma reserva Tukuna. Dissertação (Mestrado em Antropologia Social) - Programa de Pós-Graduação em Antropologia Social, Universidade de Brasília, Brasília, 1977.

PALMEIRA, Moacir. Voto: Racionalidade ou significado?. Revista Brasileira de Ciências Sociais, n. 20, p. 26-30, out. 1992.

PALMEIRA, Moacir. Política, Facções e Voto. In: PALMEIRA, Moacir; GOLDMAN, Marcio (org.). Antropologia, voto e representação política. Rio de Janeiro: Contra Capa Livraria, 1996.

PALMEIRA, Moacir; HEREDIA, Beatriz. Le Temps de la politique. Études rurales, n. 131-132, p. 73-87, 1993.

PALMEIRA, Moacir. Eleição municipal, política e cidadania. In: PALMEIRA, Moacir; BARREIRA, César. Política no Brasil: visões de antropólogos. Rio de Janeiro: Relume Dumará, 2006.

STRECK, Lenio Luiz. Lawfare. In: ALVES, Giovanni (coord.). Enciclopédia do Golpe, Bauru: Canal 6, v. 1, 2017. 
TONELLI, Maria Luiza Quaresma. Judicialização da política. In: ALVES, Giovanni (org.). Enciclopédia do Golpe, Bauru: Canal 6, v. 1, 2017.

VERBICARO, Loiane Prado. Um estudo sobre as condições facilitadoras da judicialização da política no Brasil. Revista Direito $G V$, v. 4, n. $2,2008$.

VIANNA, Luiz Werneck; CARVALHO, Maria Alice R.; MELO, Manuel Palácios Cunha; BURGOS, Marcelo Baumann. A judicialização da política e das relações sociais no Brasil. Rio de Janeiro: Ed. Revan, 1999.

VIANNA, Luiz Werneck; BURGOS, Marcelo Baumann; SALLES, Paula Martins. Dezessete anos de judicialização da política. Tempo Social Revista de Sociologia da USP, v. 19, n. 2, 2007.

VILLELA, Jorge Mattar. O dinheiro e suas diversas faces nas eleições municipais em Pernambuco. Mana, v. 11, n. 1, p. 267-296, 2004.

WACQUANT, Loïc. Corpo e Alma: notas etnográficas de um aprendiz de boxe. Rio de Janeiro: Relume Dumará, 2002.

ZALUAR, Alba. A Máquina e a revolta: as organizações populares e o significado da pobreza. 2 ed. São Paulo: Brasiliense, 2000.

ZANIN, Cristiano; MARTINS, Valeska; VALIM, Rafael. Lawfare: uma introdução. São Paulo: Contra Corrente, 2019.

ZENOBI, Diego. O Antropólogo como "espião": das acusações públicas à construção das perspectivas nativas. Mana, v. 16, n. 2, p. 471-499, 2010.

SUBMETIDO EM: 06/12/2019

APROVADO EM: 19/10/2020 